\title{
COMPANION CELLS IN BAST OF GNETUM AND
}

\section{ANGIOSPERMS}

W. P. TномPSON

\section{(WITH SEVEN FIGURES)}

The presence of companion cells in the bast of angiosperms is one of the constant anatomical features which distinguish that great group of plants from the gymnosperms. On account of the technical difficulties in the study of bast tissue in general, little emphasis has been attached to this distinction, although it is really quite as valuable as the familiar one based on the presence of vessels in angiospermic wood. The elements in question are designated companion cells, because almost invariably one of them is associated with each sieve tube. They are small, vertically elongated, parenchymatous cells which have special characteristics that will be described later, and which have no counterpart in the bast of gymnosperms.

In a study of the anatomy of the Gnetales $(3,5)$, it became clear that the same elements or ones remarkably similar are to be found in the bast of Gnetum. Another clear-cut characteristic is therefore added to the long list of features in which Gnetum departs from gymnospermic structure and resembles angiosperms. It has been shown (5), however, that one of the most striking of these resemblances, the possession of vessels, is not the result of a genetic connection between Gnetum and angiosperms, because the vessels have been evolved in entirely different ways in the two groups. It becomes necessary, therefore, to examine and compare the angiospermic and Gnetalean companion cells both as to structure and as to development.

\section{Companion cells of angiosperms}

Angiospermic bast as found in Aristolochia macrophylla (Lam.) is represented in fig. I. Two chief kinds of elements are visible: the clear, irregularly shaped sieve tubes, and the richly protoplasmic parenchymatous cells (in most sections of bast there are 
in addition thick-walled fibers constituting the so-called hard bast). The parenchymatous elements are in turn plainly of two kinds: large cells containing starch grains, which are represented in black as if stained with iodine, and much smaller, starchless elements. The latter are the companion cells, whereas the former are ordinary storage parenchyma. A further difference between the two kinds appears in longitudinal sections; the companion cells are highly elongated vertically, while the ordinary storage parenchyma cells are rectangular. It should be noted that a

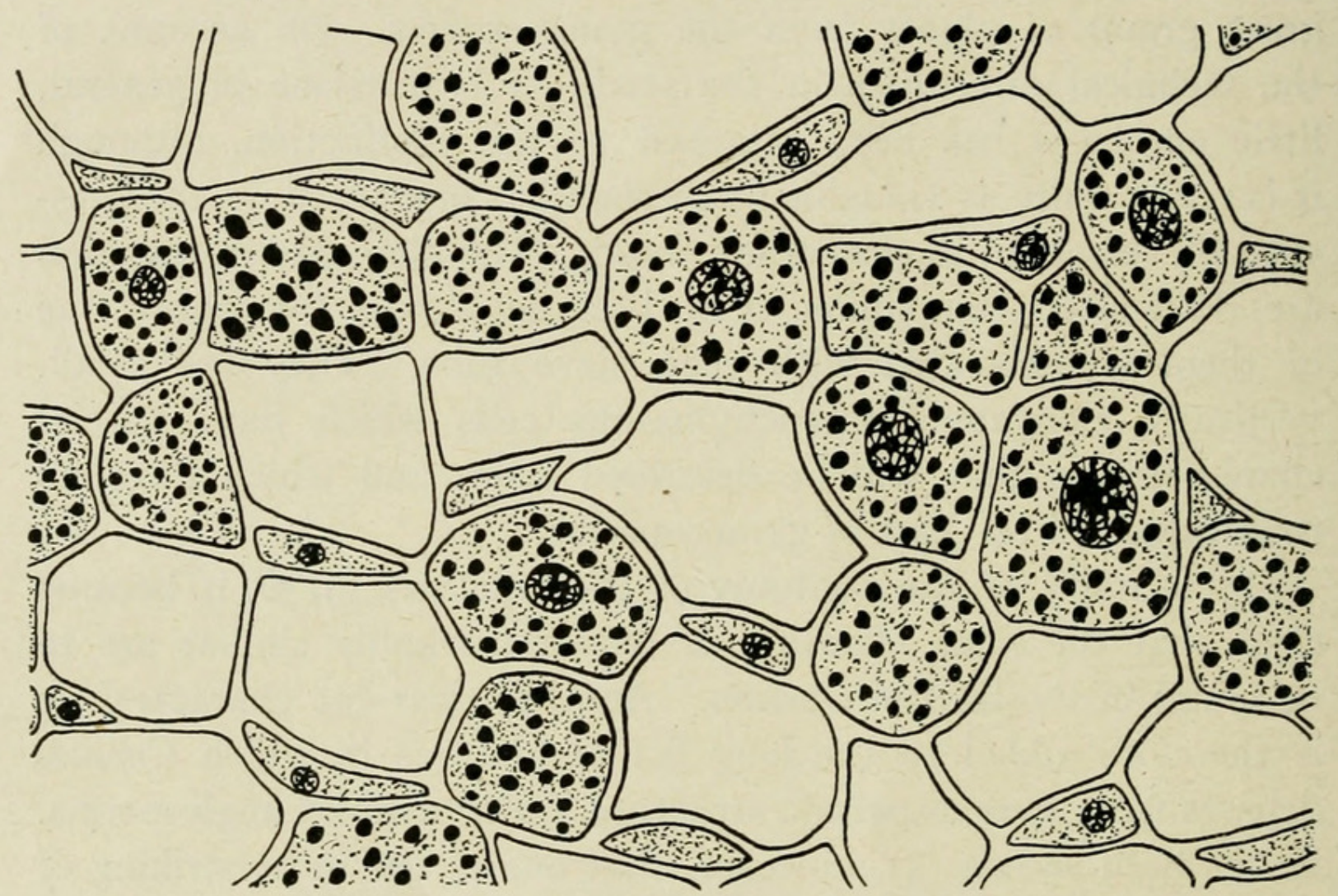

FIG. I.-Mature bast of Aristolochia macrophylla (Lam.); $\times$ Iоo०

companion cell is associated with each sieve tube and is frequently fitted snugly into one corner of the tube.

The bast of Aristolochia was chosen for illustration because its elements exhibit a more orderly arrangement than is usual in angiosperms. In many species the rows of phloem cells formed at the cambium very quickly become so distorted that the orderly sequence is lost, and the cells of the mature bast then appear to be haphazardly placed. In Aristolochia, however, the rows of cells are to a certain extent preserved in the mature bast, as may be seen in fig. I. When this is the case, there is a significant 
indication of relationship between sieve tube and companion cell. The relative positions of these two elements is such as to indicate that they are formed from two successive cells in a row, and that they are products of the same mother cambial cell. This relationship was mentioned long ago by DEBARY (I): "Both from their arrangement in cross-section and on tracing them in the longitudinal direction, it often has the appearance as if the cambiform cells arose with the elements of the sieve tubes from one mother

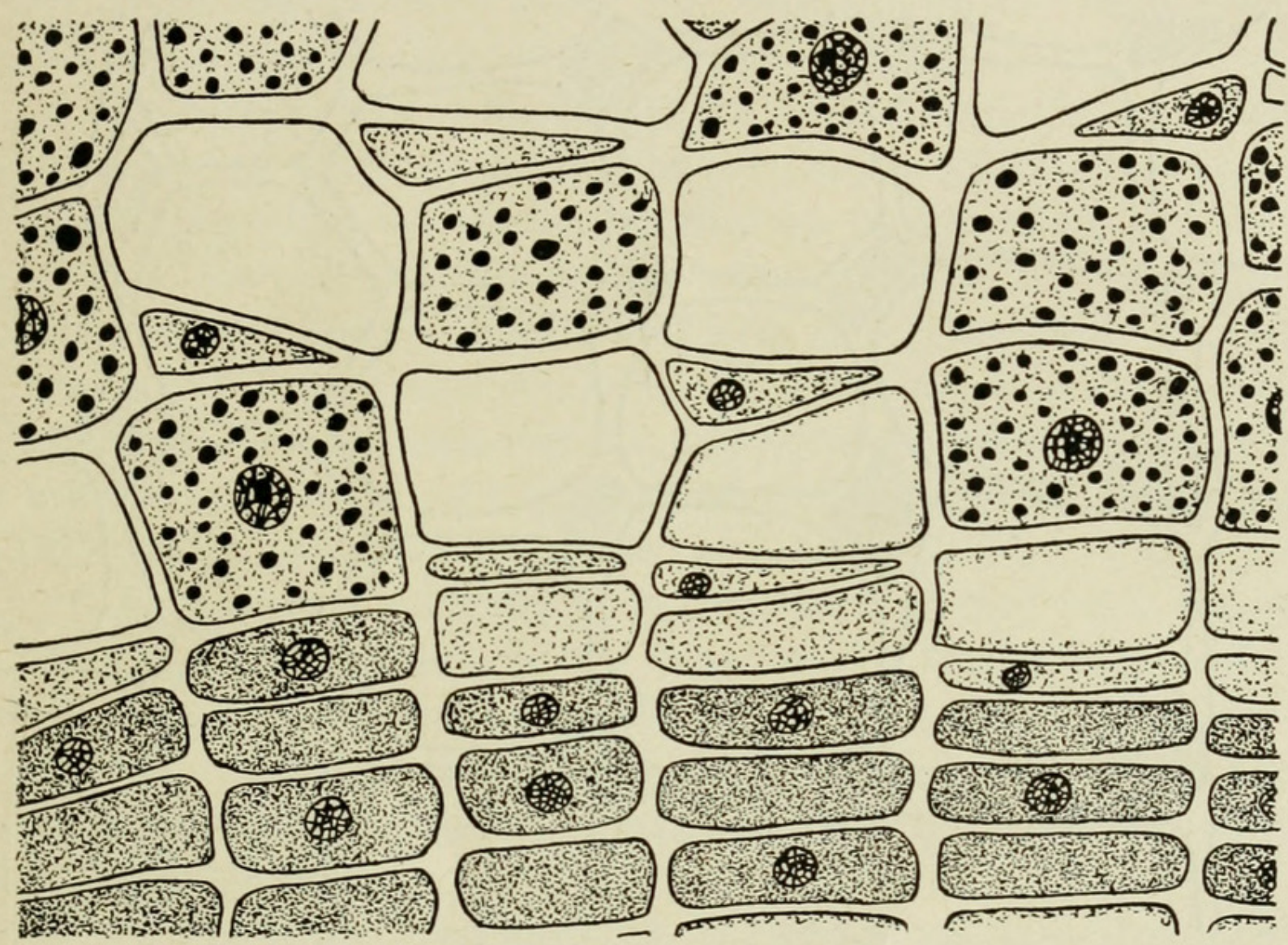

Fig. 2.-Cambium and young bast of Aristolochia macrophylla (Lam.) showing each sieve tube and its companion cell formed from contiguous cells in same row; $\times$ Iooo.

cell, the latter dividing longitudinally into a daughter cell which becomes the sieve tube element, and another which becomes a cambiform cell without further division or is divided by cross walls into several of them." Strasburger (2) later made the definite statement that companion cells and sieve tubes are sister cells.

This statement is of course to be confirmed or disproved by an examination of the method in which the bast develops in the cambial region. The process as it occurs in Aristolochia is illustrated in fig. 2. As one traces the rows of cambial cells in the 
lower part of the figure into the bast of the upper part, it becomes perfectly clear that each sieve tube and its companion cell are derived from contiguous cells in the same row, and that as the bast matures the companion cell tends to become shifted to one corner of the sieve tube. I have not been able to show that sieve tube and companion cell are products of one division. In fact, judging from what we know of cambial activity, it seems more probable that they are products of two successive divisions, in

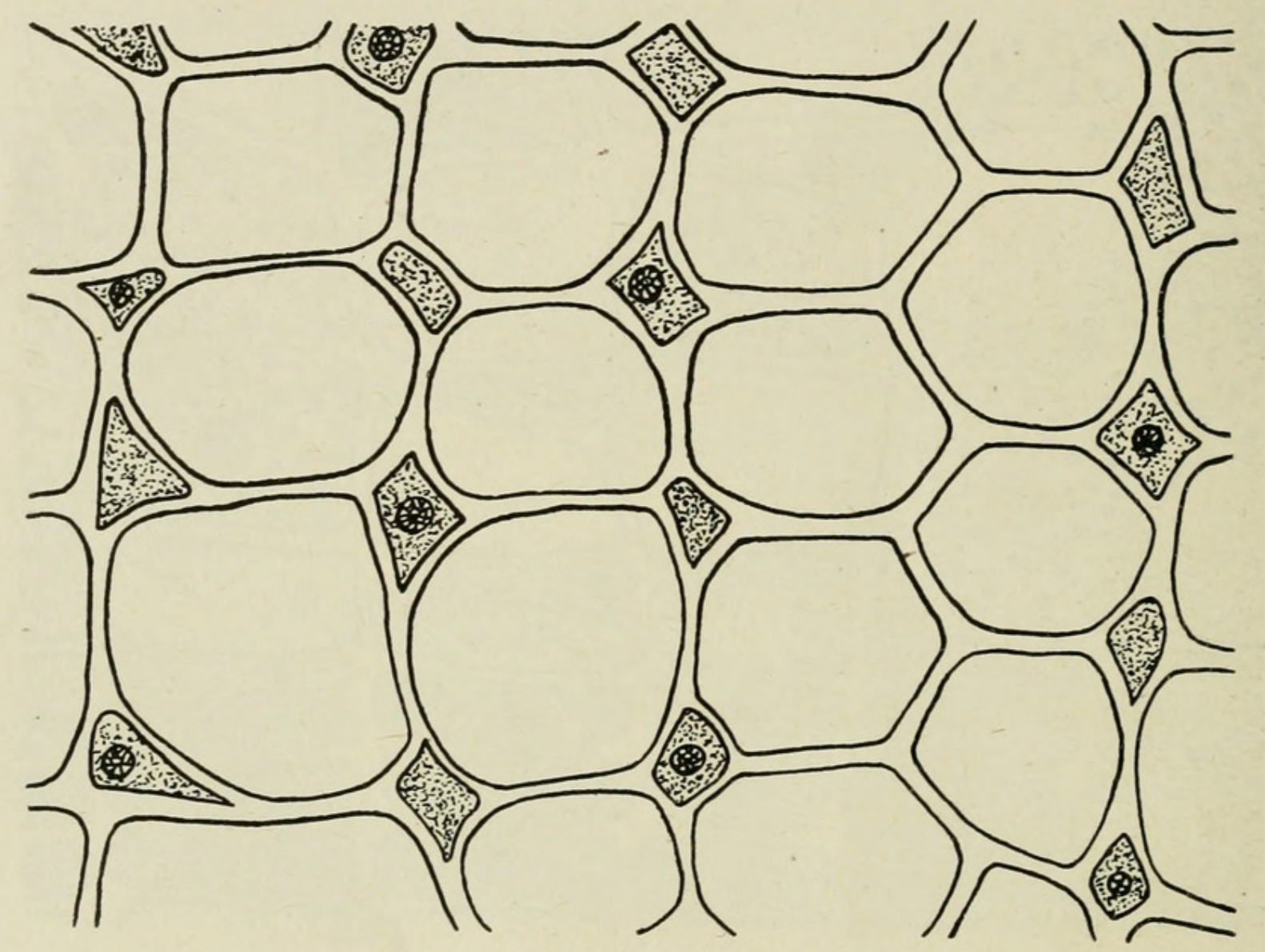

FIG. 3.-Mature bast of Gnetum latifolium showing sieve tubes and companion cells; $\times$ rooo.

each of which one daughter (the innermost) remains cambial. In other words, they are probably not sisters but aunt and niece. However that may be, for the purposes of the present discussion the important conclusion is that they are successive members of a single row of cambial products.

\section{Companion cells of Gnetum}

The mature bast of several species of Gnetum (fig. 3) consists of only two kinds of elements, large clear sieve tubes and small parenchymatous cells. The latter evidently correspond to the 
companion cells of angiosperms, as is shown by their small size, their association with sieve tubes, their location in the corners of the sieve tubes, their lack of starch, and their great elongation in the vertical direction. Storage parenchyma of the ordinary type (not rays) as found in angiosperms is absent. Sieve tubes and companion cells are arranged with great regularity, the former in very uniform rows and the latter in the angles between the tubes. Usually there is an interrupted row of companion cells for every row of sieve tubes, but occasionally the former are lacking, as may be seen toward the right of fig. $3 \cdot{ }^{\mathrm{I}}$

The development of the bast at the cambial region is illustrated in fig. 4. It will be seen that the companion cells are formed in radial rows which are continuous through the cambium, and that in these rows sieve tubes are not formed. There is a tangential alternation of cambial rows which form sieve tubes with cambial rows which form companion cells. Both are never formed in the same row. As the bast matures and the sieve tubes expand, the rows of companion cells become interrupted and the individual cells pushed to the corners of the sieve tubes.

This process is evidently quite different from that which occurs in angiosperms, because in the latter sieve tube and companion cell are invariably successive cells in the same row. There is no separate cambial mother cell for the companion cells. Thus the similar mature condition is brought about in quite different ways in the two groups.

A study of the wood adjacent to the cambium, also illustrated in fig. 4, reveals an unexpected relationship between the companion cells and the parenchyma of the wood. The same cambial rows which form companion cells outwardly also form rows of wood parenchyma cells inwardly. The latter with their protoplasm are easily distinguished in the figure from the empty, thick-walled wood fibers which are formed in rows by the same cambial cells which form sieve tubes. The rows of wood parenchyma formed in this way are readily mistaken for uniseriate rays, but longitudinal

I It may be remarked that the bast of Gnetum is extremely favorable material, both for original study and for class use. The sieve areas are remarkably abundant and of great size, and the individual pores are very large and clear. Moreover, the whole tissue and the connected cambium are not easily crushed in sectioning. 
sections show that they are typical, vertically elongated wood parenchyma. The rays of Gnetum are multiseriate or broad.

The appearance of this parenchyma in the mature wood is shown in fig. 5. At the end of the season's growth, where the fibers are small and vessels lacking, the wood parenchyma forms continuous rows (lower part of figure), but with the increase in size of the fibers and the introduction of vessels at the beginning of the next season's growth, the parenchymatous cells become

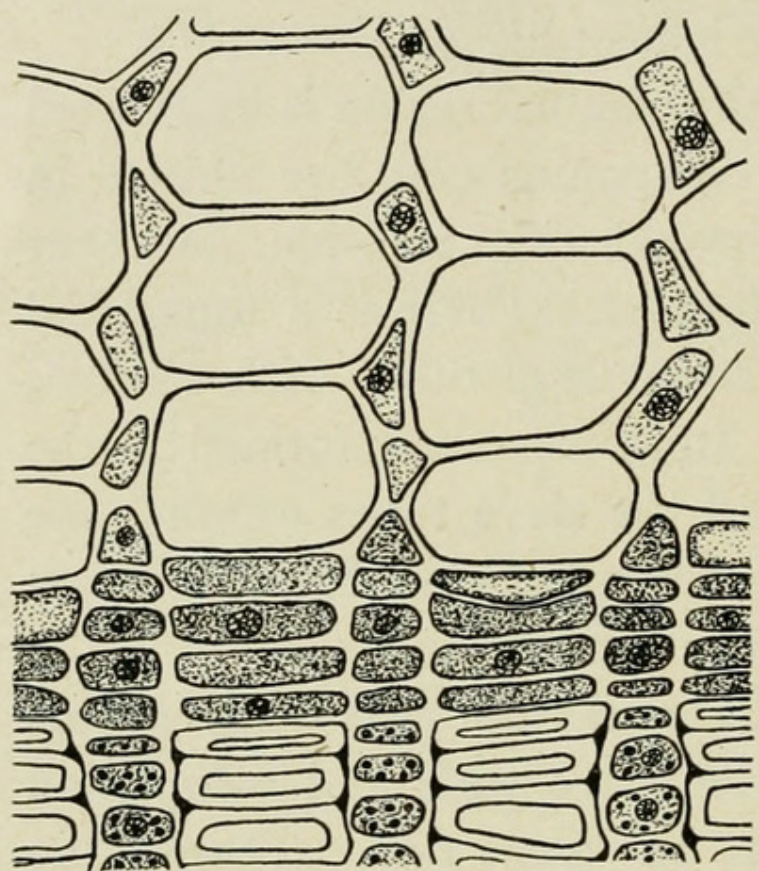

FIG. 4

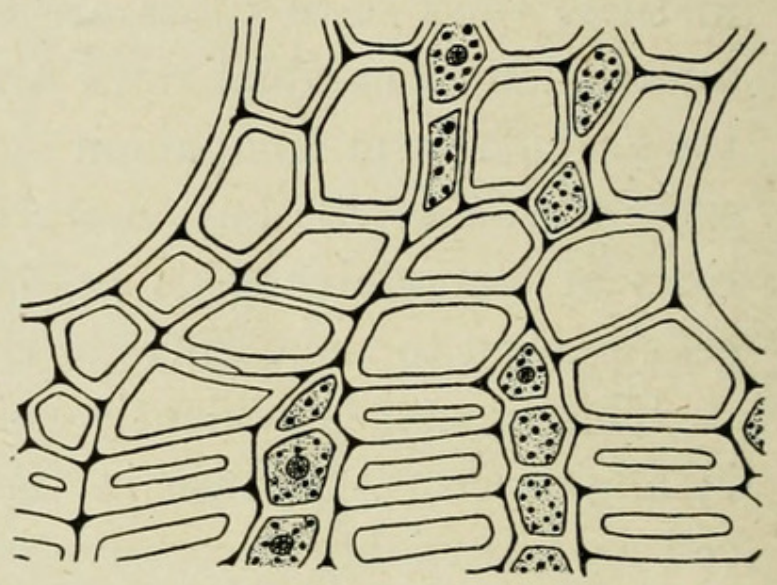

FIG. 5

Figs. 4-5.-Fig. 4, wood, cambium, and young bast of Gnetum latifolium showing sieve tubes and companion cells formed from different rows of cambial cells; also wood parenchyma formed inwardly from those cambial cells which form com-

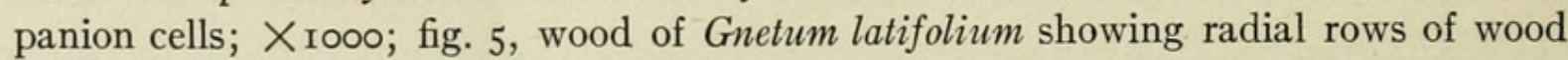
parenchyma; $\times$ זоoo.

separated just as do the companion cells of the bast. Often where the vessels are large the rows of elements of all sorts become so distorted that they can no longer be traced. The elements then appear to be haphazardly arranged.

In certain regions of some species of Gnetum particularly interesting and primitive conditions of the companion cells are found. In the root of $G$. scandens, for example, the companion cells do not become separated and relegated to the corners of the sieve tubes, but form continuous rows, even in old bast. This condi- 
tion of affairs is illustrated in fig. 6. At the top of the figure, although the bast is old and beginning to collapse, the companion cells are still in continuous rows. This condition is frequently found in roots, young stems, and reproductive axes. It evidently represents a retention of a primitive condition.

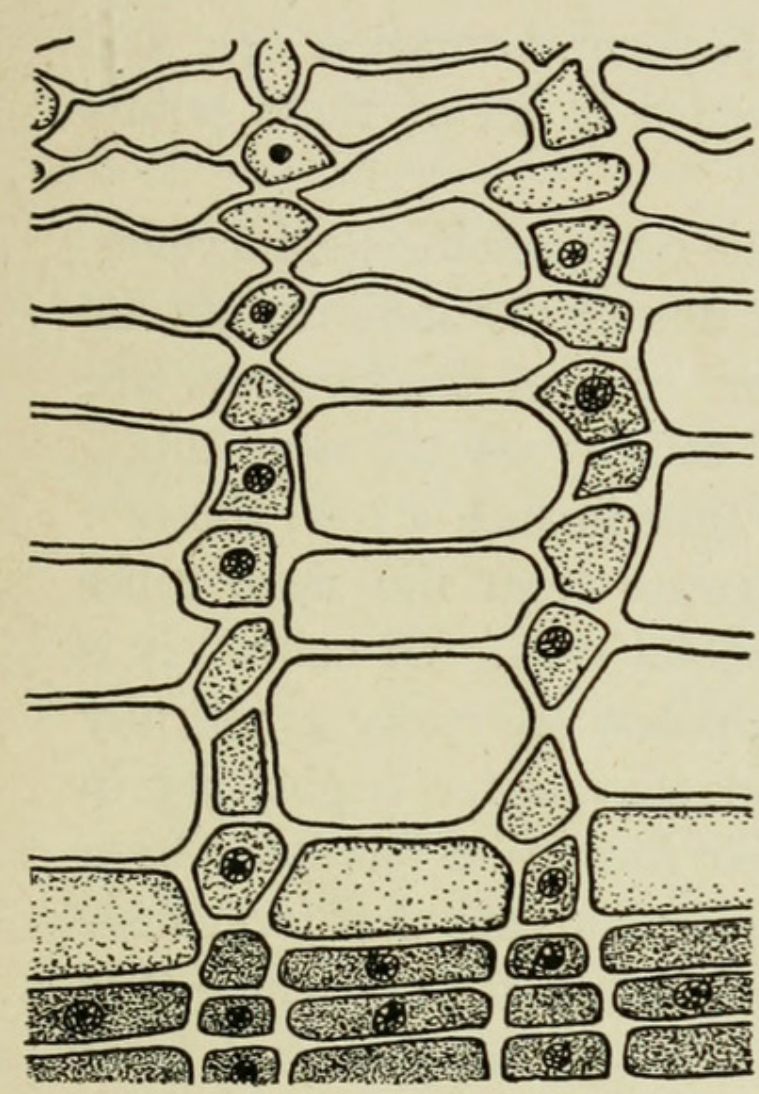

Fig. 6

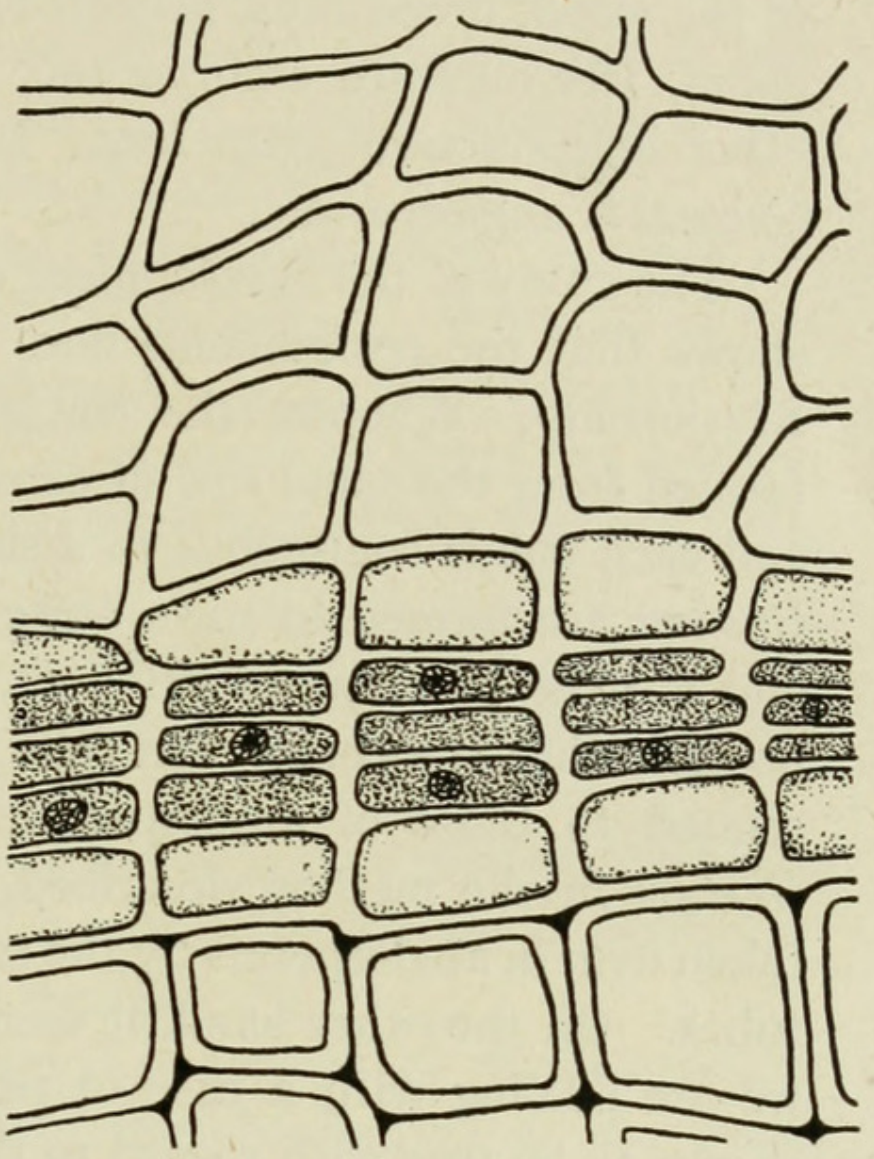

FIG. 7

Figs. 6-7.-Fig. 6, cambium and bast of root of Gnetum scandens showing

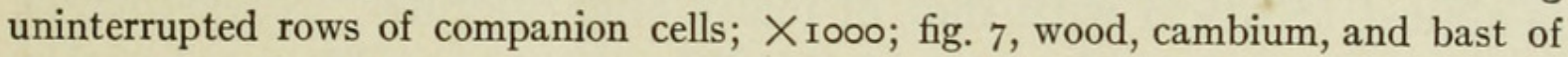
young stem of Gnetum moluccense showing absence of companion cells and wood parenchyma; X $\mathrm{\text {Iooo. }}$

Again, in certain regions of some species companion cells are entirely absent, the bast then consisting entirely of sieve tubes and rays. This is illustrated in fig. 7 , from the young stem of $G$. moluccense. When this is the case, wood parenchyma is also lacking, as might be expected from the relationship which has been shown to exist between companion cells and wood parenchyma. The absence of companion cells has been noted in seedlings of several species and in reproductive axes, as well as in roots and young stems. 


\section{Discussion}

The presence in the bast of Gnetum of companion cells which are in most respects of the angiospermic type is at first sight another striking indication of real relationship between Gnetum and angiosperms. They are to be compared with the vessels of the wood, broad rays, general habit, style (4), absence of archegonia, free-nucleate embryo sac, endosperm formation (4), and other reproductive characters. In regard to all of these points Gnetum is angiospermic.

The study of the development of the companion cells, however, shows that the resemblance does not necessarily indicate genetic relationship. Whereas the companion cells of angiosperms are formed from the same row of cambial cells as are the sieve tubes, and each one is contiguous to a sieve tube in such a row, those of Gnetum are formed in rows quite separate from the sieve tubes and are the products of different cambial cells. Of course, it is possible that the companion cells of Gnetum are really genetically related to those of angiosperms, and that, after originating in Gnetum in the method described, their formation has later been taken over in angiosperms by the same cambial cells that form sieve tubes. On the other hand, it seems more logical to conclude that we are dealing with a case of parallel evolution, just as I have shown to be true with regard to the vessels of the wood (5). The vessel of Gnetum with a single large perforation in the end wall is almost identical with that of many angiosperms. Nevertheless, it has been evolved in an entirely different way. The perforation of the angiospermic porous vessel has resulted from the breaking down and disappearance of scalariform bars, whereas that of Gnetum has resulted from the enlargement of typical, circular, haphazardly arranged, bordered pits accompanied by the disappearance of the middle lamellae, the enlargement proceeding until the intervening portions of the vessel wall have vanished. In the case of the companion cell we seem to have a close parallel to that of the vessel. While the completed structure is similar to that of angiosperms, the course of its development is quite different.

If two such striking points of resemblance as vessels in the wood and companion cells in the bast are really results of inde- 
pendent evolution in Gnetum and angiosperms, the inference is natural that other resemblances may be in the same category.

\section{Summary}

I. Companion cells resembling those of angiosperms in size, in their association with sieve tubes, in their usual location in the angles of the sieve tubes, and in their vertical elongation, are present in the bast of some species of Gnetum.

2. The development of these companion cells, however, is quite different from that found in angiosperms. Whereas, in the latter, each sieve tube and its companion cell are derived from two successive cells in a single row of cambial products, in Gnetum sieve tubes and companion cells are produced from different rows of cambial cells.

3. Although the completed forms of companion cell in the two groups are similar, they have probably been independently evolved.

4. Primitive conditions in which companion cells are lacking, or in which continuous rows of companion cells are present, are found in certain regions of some species.

5: The parenchyma of the wood is formed by those cambial cells which form companion cells; the distribution of the wood parenchyma is consequently in radial bands, which frequently become interrupted by the expansion of vessels and fibers.

\section{UNIVERSITY OF SASKatcheWAN}

Saskatoon, Sask.

\section{LITERATURE CITED}

I. DeBary, A., Comparative anatomy of Phanerogams and Ferns. Oxford University Press. I884.

2. Strasburger, Noll, Schenk, and Karsten, Textbook of Botany. Macmillan. I9r2.

3. Thompson, W. P., The anatomy and relationships of the Gnetales. I. The genus Ephedra. Ann. Botany 27:1077-1102. I912.

4. —- The morphology and affinities of Gnetum. Amer. Jour. Bot. $4: 135-184$. I9I6.

5. - Independent evolution of vessels in Gnetales and Angiosperms. Вот. GAz. 65:83-90. I918. 


\section{$2 \mathrm{BHL}$ Biodiversity Heritage Library}

Thompson, W. P. 1919. "Companion Cells in Bast of Gnetum and Angiosperms." Botanical gazette 68(6), 451-459. https://doi.org/10.1086/332583.

View This Item Online: https://www.biodiversitylibrary.org/item/27441

DOI: https://doi.org/10.1086/332583

Permalink: https://www.biodiversitylibrary.org/partpdf/224516

\section{Holding Institution}

New York Botanical Garden, LuEsther T. Mertz Library

\section{Sponsored by}

MSN

\section{Copyright \& Reuse}

Copyright Status: NOT_IN_COPYRIGHT

This document was created from content at the Biodiversity Heritage Library, the world's largest open access digital library for biodiversity literature and archives. Visit BHL at https://www.biodiversitylibrary.org. 